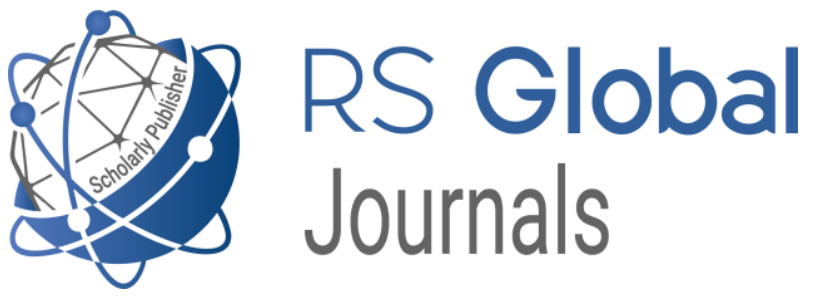

Scholarly Publisher

RS Global Sp. z O.O.

ISNI: 0000000484952390

Dolna 17, Warsaw, Poland 00-773

Tel: +48226022703

Email: editorial_office@rsglobal.pl

JOURNAL International Journal of Innovative Technologies in Social Science

p-ISSN

2544-9338

e-ISSN

2544-9435

PUBLISHER

RS Global Sp. z O.O., Poland

ARTICLE TITLE

МУЗИЧНА ІКОНОГРАФІЯ В ТВОРЧОСТІ

3. КУРЧИНСЬКОГО (ЖАНРИ, СТИЛІ, ХРОНОТОП)

AUTHOR(S)

Великанич Софія

Velykanych Sofiia. (2020) Musical Iconography in the Works of

ARTICLE INFO

Z. Kurchynsky (Genres, Styles, Chronotope). International Journal of Innovative Technologies in Social Science. 7(28).

doi: 10.31435/rsglobal_ijitss/30122020/7237

DOI

https://doi.org/10.31435/rsglobal_ijitss/30122020/7237

RECEIVED

13 October 2020

ACCEPTED

28 November 2020

PUBLISHED

03 December 2020

(c) (7)

LICENSE

This work is licensed under a Creative Commons Attribution

4.0 International License.

(C) The author(s) 2020. This publication is an open access article. 


\title{
МУЗИЧНА ІКОНОГРАФІЯ В ТВОРЧОСТІ З. КУРЧИНСЬКОГО (ЖАНРИ, СТИЛІ, ХРОНОТОП)
}

\author{
Великанич Софія, \\ аспірантка кафедри теорії та історії культури НМАУ ім. П.І. Чайковського, м. Київ, Украӥна, \\ ORCID ID: https://orcid.org/0000-0003-0896-7171
}

DOI: https://doi.org/10.31435/rsglobal_ijitss/30122020/7237

\section{ARTICLE INFO}

Received 13 October 2020

Accepted 28 November 2020

Published 03 December 2020

\section{KEYWORDS}

sculptural decoration, secession, modernism, musical iconography, Z. Kurchynsky.

\begin{abstract}
The article highlights the figure of a prominent Lviv sculptor and graphic artist of Polish origin, who clearly showed his creative personality in the decor of architectural structures of Lviv and other forms of sculptural specimens in the late XIX - early XX centuries. The found samples of the artist's appeal to musical symbolism and figures of musical culture in monumental and portrait sculpture are analyzed. The genre classification of the found artifacts in the declared subject is carried out, and also samples from group of a sculptural ornament as key in research are analyzed in detail. The search for sources of such interest in the creative biography of the artist and the establishment of causal links in the context of artistic processes of the time. Emphasis is placed on the role of personalities who met on the artistic path of the sculptor, as well as on specific examples of their influence on the creative realization of Z. Kurchynsky.
\end{abstract}

Citation: Velykanych Sofiia. (2020) Musical Iconography in the Works of Z. Kurchynsky (Genres, Styles, Chronotope). International Journal of Innovative Technologies in Social Science. 7(28). doi: 10.31435/rsglobal_ijitss/30122020/7237

Copyright: (C) 2020 Velykanych Sofiia. This is an open-access article distributed under the terms of the Creative Commons Attribution License (CC BY). The use, distribution or reproduction in other forums is permitted, provided the original author(s) or licensor are credited and that the original publication in this journal is cited, in accordance with accepted academic practice. No use, distribution or reproduction is permitted which does not comply with these terms.

Вступ. Аналізуючи культурно-мистецьку ситуацію у Львові на початку XX ст., зокрема iii архітектурну складову, дослідник зустрічається з великою кількістю персоналій, кожна $з$ яких здійснила свій внесок у створення міського простору. Не всі імена в рівній мірі досліджувались раніше, тому заповнювати інформаційні лакуни в даному аспекті $є$ надзвичайно важливим. Оскільки нами вивчається вузькоспеціалізована галузь музичної іконографії, намагатимемось поглибити знання про постать, яка в цій сфері проявила себе особливо яскраво. Саме тому у статті досліджується творчість 3. Курчинського як творця музичної іконографії в декорі львівської архітектури на початку XX ст.

Вивчаючи тему такого типу дослідник стикається із необхідністю залучати до роботи різні наукові напрямки, тобто спрямовувати дослідження у міжвидове русло. Історія архітектури, культурологія, мистецтвознавство, музикознавство - всі ці сфери покликані відшукати цікаві факти, важливі для них всіх загалом і для кожної окремо. Тобто, дослідження у вузькому профілі розширює свої можливості користуючись засобами і знаннями вже досліджених тем.

Матеріали і методи. В якості методологічного інструментарію застосовується класифікація віднайдених зразків для структуризації дослідження та органічної інтеграції артефактів в культурно-стильовий контекст початку століття. Крім того, в статті сформовано схему аналізу конкретної мистецької постаті, з огляду на вибір нею аспекту творчої діяльності, та причин, які до цієї творчості спонукали. Враховуючи універсальність такого методу, за його допомогою можна досліджувати різні ракурси мистецької науки, через персоналії, які це мистецтво творять.

Дослідження базується на віднайдених зразках музичної іконографії в творчості 3. Курчинського, виявлених як на архітектурних об'єктах, так і в музейних колекціях. 
Різножанровість артефактів провокує класифікувати їх за різними критеріями для логіки розвитку наукового пошуку.

Актуальність дослідження. Заглиблюючись у тематичний контекст наукових розвідок культури Львова межі XIX і XX ст. стає очевидним той факт, що тем для дослідження є значно більше, ніж дослідників. Музична іконографія як галузь пропонує безліч проблемних зон, актуальність дослідження яких важко переоцінити. Крім того, аналіз мистецьких артефактів напряму пов'язаний з їх творцями, тому актуальність даної статті полягає у висвітлені цікавої і мало вивченої особистості 3. Курчинського з точки зору створення ним музичної іконографії у Львові на зламі століть.

Аналіз останніх досліджень та публікацій. Звертаючись до культурно-історичного періоду кінця XIX - поч. XX ст. у Львові беззаперечним лідером наукової думки є Ю. Бірюльов. Його дослідження сецесії як стилю загалом (є одним із ключових у зразках музичної іконографії того періоду) і архітектури зокрема стали для нас фактологічним фундаментом. Крім того, науковець вивчав також i постать 3. Курчинського як скульптора - одного 3 творців архітектурного обличчя міста зазначеного періоду (Бірюльов, 2015). Також до аналізу залучались статті, які стосуються організації «Молода муза», з якою був пов'язаний 3. Курчинський, а саме роботи А. Матусяк (Матусяк, 2008) та С. Нісевич (Нісевич, 2012). Огляд стильових тенденцій проводили А. Банцекова (Банцекова, 2006), І. Жук (Жук, 1989), Я. Костко (Костко, 2014) та інші.

Виклад основного матеріалу дослідження. Досліджуючи тему музичної іконографії в архітектурній оздобі Львова кінця XIX- початку XX ст. стикаємось із персоналіями, які були безпосередньо залученими до творення міста. В цей період архітектурна забудова відбувалась надзвичайно активно, чим спричиняла великий попит на професіоналів у цій сфері. Львівська художньо-промислова школа та Львівська політехніка займались якісною підготовкою кадрів. За власними підрахунками в той час у Львові працювало близько двохсот архітекторів та п'ятдесяти скульпторів, 3 чого можемо зробити висновок про велику популярність i затребуваність архітекторського ремесла у Львові на межі століть.

Однак, не кожен проявив себе настільки яскраво як Зигмунд Курчинський (1886-1953) скульптор, графік та художній критик польського походження, який став яскравим явищем в історії архітектури Львова, а саме їі скульптурної оздоби. Володіючи непересічним талантом і отримавши добру освіту як у Львові, так і за кордоном (в Кракові та Парижі), він реалізувався як декоратор архітектурних споруд та портретний скульптор у рідному місті, інтегрувавши європейські стильові тенденції у львівський контекст (Бірюльов, 2010).

Для нас особливо важливою $є$ не творчість скульптора загалом, а конкретна ії частина. Досліджуючи зразки музичної іконографії в скульптурній оздобі будівель львівського середмістя перш за все виникає потреба визначити її авторство. Виявилось, що 3. Курчинський частіше від інших своїх колег звертався у своїй творчості до музичних мотивів. Більше того, він реалізовував їх також і в пластичних роботах та скульптурних портретах. Тому, ми спробуємо вияснити причини такого частого звернення митця до музичної тематики і зрозуміти ті фактори (як життєві, так і мистецькі) які спонукали до цього

3 точки зору наукової послідовності класифікуємо зразки музичної іконографії в творчості 3. Курчинського, адже митець проявив себе в даному аспекті як у архітектурній оздобі, так і в скульптурній пластиці і осмислення його мистецького доробку потребує певної мірі структуризації. Така типологія може стати корисною на етапі виходу роботи на рівень узагальнення:

1). Погруддя:

- «Музикант» (1910) - символічне зображення людини з віолончеллю на спині, яка йде проти вітру (Бірюльов, 2005, С. 148). Фігура зігнута, в ній передається важкий крок і зусилля, які докладає музикант, щоб його зробити. Можемо припускати, що скульптор прагнув в метафоричному ключі передати долання перешкод, які виникають на шляху кожного митця.

- «Портрет молодої людини» (1905) - єдиний збережений скульптурний портрет часів навчання у дусі академічного реалізму, який по зовнішніх характеристиках нагадує постать Ф. Шопена. Скульптура була продемонстрована в 1911 році на «Виставці трьох» (Бірюльов, 2015, C. 320).

- «Голова Бетховена» (1910) - скульптурний портрет композитора, виконаний під час другого перебування Курчинського в Парижі. Очевидно, був створена під впливом «Трагічної маски Бетховена» Е.А. Бурделя (1901) (Бірюльов, 2015, С. 323). 
2). Скульптурна оздоба: найбільш обширна група. До неї відносимо будинки на вул. Городоцькій, 117 (1911), Дорошенка, 14 (1912), Наливайка, 6 (1912), Валовій, 13 (1913), Гнатюка, 20-22 (1911) та Пекарській, 5 (1912). Тут присутні як сюжетні сцени, так і окремі музичні інструменти.

3). Плакетки: відомо про наявність двох гіпсових плакеток із зображенням Ф. Шопена, одна 3 яких знаходиться у фондах Львівського історичного музею і була створена в 1912 p. Дослідник Ю. Бірюльов вбачає в ній впливи архаїчної стилістики Е.А. Бурделя (Бірюльов, 2015, C. 912).

4). Ілюстрація нотної збірки: серед тогочасної періодики віднайдено один зразок ілюстрації 3. Курчинським збірки революційних пісень 1919 р. польською мовою (Стара львівська реклама, 2014).

Враховуючи зазначені ключові завдання статті розглянемо декілька найяскравіших зразків музичної іконографії в скульптурній оздобі архітектурних споруд у творчості 3. Курчинського з точки зору їх образного наповнення та можливих мотивів їх появи.

Першим 3 них буде будинок на вул. Гнатюка 20-22, споруджений за проектом Ф. Касслера та Р. Фелінського (архітектурне бюро М. Уляма). Прибутковий будинок, який виділяється із загального ансамблю модерновою пластикою 3. Курчинського (Бірюльов, 2005, C.45). Портал брами входу прикрашають каріатиди, які явно створенні під впливом, популярної на той час науки, єгиптології. Крім того, достовірно відомо, що Курчинський, ще перебуваючи на навчанні в майстерні О. Родена в Парижі проявляв цікавість до архаїки. 3 точки зору музичної іконографії для нас цікавою є ліпнина над вікнами другого поверху. Людське обличчя (припускаємо, чоловіче) імітує гру на струнно-щипковому інструменті (атрибутувати точно не можливо, оскільки видно лише струни). Звичайно, зображення носить символічний характер, але спосіб яким скульптор його втілює наштовхує на певні ідеї. Постать знаходиться в межах квадратної рамки, але не вписується туди, за рахунок чого створюється ефект руху назовні. Можемо припустити, що тут скульптор хотів передати зібраний образ митця-модерніста, який шукає шляхи виходу за рамки старих утверджених принципів в мистецтві, а також за рамки власних можливостей.

Різноманіття варіантів стильових трансформацій у львівській архітектурі демонструє будинок на вул. Городоцькій, 117, збудований в 1911 p. за проектом Г. Орлеана та Е. Скавінського. Стиль споруди мистецтвознавці визначають як неороманськонеомавританський, який реалізовано не в останню чергу завдяки скульптурній оздобі 3. Курчинського, адже саме ліпнина створює неповторний вигляд фасаду в такому оригінальному стилі (Lwów. Ilustrowany przewodnik, 2003, S. 153).

Особливої уваги вартують орнаментальні мотиви, присутні у металевих конструкціях (балконних огорожах та брамі), а також обрамлюють віконні отвори. Зразки музичної іконографії представлені у підвіконних тафлях, розміщених між поверхами - це маленькі путті, один $з$ яких грає на музичному інструменті, схожому на гітару (інструмент характерний для мавританської культури), інший - на пан-флейті. В цьому зразку, як і в попередньому, скульптурні фігури не вписуються у форму i, ніби, «оживають», за рахунок чого створюється ілюзія руху. Варто зауважити, що образ путті був досить актуальним серед оздоблювачів архітектури на зламі епох і їхня іконографія склалася доволі стереотипно - веселі пухкенькі діти, які танцюють, або грають на лірі чи духовому інструменті. В даному випадку путті мають нахмурений вираз обличчя і зовсім не слов'янську зовнішність.

Припускаємо, що скульптор підійшов до реалізації мавританського стилю 3 усією відповідальністю, надавши правдоподібності не лише орнаментальній стороні декору, а й рисам обличчя скульптур. Цей факт засвідчує високий рівень скурпульозності митця у роботі над образом і в увазі до стильової точності своїх творінь, адже зважаючи на ті тенденції, що існували в мистецтві того періоду, стильова строкатість і еклектика була абсолютно прийнятною і він міг дозволити собі експерименти в даному руслі.

Однак, творчість Курчинського загалом демонструє тяжіння до стильової цілісності в межах одного об'єкту, що не збіднює різноманіття рішень у творчих проявах в цілому. Можемо сміливо називати це рисою творчості З. Курчинського.

Третім прикладом яскравої реалізації музичної іконографії в архітектурній оздобі Львова в творчості Курчинського є будинок по вул. Наливайка, 6. Це житловий будинок, збудований в 1912 р. за проектом Ю. Авіна в стилі модерн (Львів. Туристичний путівник, 1999, С. 154). 
Зразки музичної іконографії знаходимо на барельєфі балконів другого поверху. Аналізуючи сюжет, що демонструється, зіштовхуємось із проблемою його прочитання та інтерпретації. О. Хмарний в статті про цей будинок припускає, що скульптор створив антропоморфне зображення бога давніх ацтеків Кетцалькоактля i, хоча, автор не посилається на жодні достовірні джерела, які б могли підтвердити цю версію, розглянемо ії як можливу, оскільки відомо, що Курчинський захоплювався мистецтвом дохристиянського Стародавнього Світу і звертався до тем, пов'язаних з ним в різних трансформаціях.

Багатоликий бородатий дід по центру і два хлопчики (не путті) по краях, один з яких курить люльку з димом, а інший грає на духовому інструменті, ймовірно сопілці (Хмарний). Тут, на відміну від попередніх розглянутих зразків зображення не надто рельєфне i відрізняється по стилю і по техніці виконання. Сюжет вписаний у композицію і чітко обрамлений. Крім того, всі три балкони абсолютно однакові, що теж відрізняє цей зразок від двох попередніх, де скульптор варіює скульптурні зображення, міняючи сюжет, персонажів і т.д. I, хоча, цей зразок явно виділяється із загальної канви індивідуального творчого почерку Курчинського, в контексті часу і місця такий архітектурний декор $є$ цілком органічним.

Здійснюючи аналіз факторів, які могли вплинути на творчу натуру скульптора здається важливим окреслення його мистецького оточення. Тут варто згадати студії у О. Родена в Парижі в 1908 році. Працюючи каменярем у майстерні О. Родена, молодий митець мав можливість відвідувати Лувр і надихатися шедеврами світової культури, а також навчатися в, на той час, досвідченого і визнаного майстра. Творчі шляхи Родена і Курчинського в деяких моментах дещо схожі. На початку кар'єри французький скульптор займався декоруванням фасадів та інтер'єрів. Згодом, здобувши певне визнання виконував скульптурні портрети на замовлення (серед яких Г. Малер), а наприкінці життя захоплювався графікою і добре реалізував себе в цьому жанрі (Бірюльов, 2010, С. 320). Схожу історія прослідковуємо і в творчій біографії 3. Курчинського.

Одразу по приїзду до Львова в 1908 р. скульптор починає працювати у власній майстерні в Палаці мистецтв, де має змогу реалізовувати ідеї і знання, привезені з Європи. Будучи неймовірно працездатним митець створював статуї і рельєфи для будинків, меморіальні об'єкти, алегоричні композиції, портретні скульптури, плакетки та медальйони, серед яких, до речі, багато на музичну тематику. Стилістично, Курчинський ще довго перебував під впливом О. Родена i творив в контексті модерних течій - сецесії, символізму та імпресіонізму (Biriulow, 2007). Отже, сміливо можна стверджувати, що вплив О. Родена на всю творчу біографію З. Курчинського був ключовим, оскільки саме в цей період були створені його найбільш яскраві творіння.

Ще однією постаттю, яка в той же період здійснила вплив на 3. Курчинського був Е.А. Бурдель - французький скульптор, який також був учнем О. Родена. Бурдель захоплювався архаїчним мистецтвом, особливо давньогрецьким. В творчості Курчинського ми зауважуємо зацікавлення культурою старовини, що, зрештою, було притаманним для митців епохи, адже модерн і його послідовники активно намагались відродити дух культури минулого в сучасній інтерпретації.

Відомо, що під час перебування в Парижі, в Луврі Курчинський багато часу проводив за дослідженням та аналізом скульптур Стародавнього Єгипту, Ассирії та грецької архаїчної культури (Бірюльов, 2015, С. 329). Результатом такого зацікавлення є будинки по вул. Гнатюка, 20-22 та Наливайка, 6. Слід підкреслити, що до статті ми залучаємо лише ті будівлі, на яких присутня музична іконографія, а стилізацій древнього світу в творчості Курчинського в межах львівської архітектури набагато більше.

Важливою рисою процесу творчості майстрів, які будували Львів на зламі століть була нерозривна єдність роботи архітектора та скульптора від початку до реалізації проекту. Саме тому сецесійні споруди несуть в собі органічне поєднання архітектури та ії оздоблення. В цьому контексті надзвичайно плідним був тандем А. Захаревича та З. Курчинського. Як вдало помічає М. Студницька «скульптурний декор немовби коментує архітектурний образ, наповнює його глибоким символічним змістом» (Студницька, 2014, С. 167). Наприклад, музичні символи на фасаді будівлі філармонії (тоді Музичне товариство Галичини) були покликані викликати музичні асоціації, оскільки це будівля спеціального призначення. Однак, ми знаходимо зразки музичної іконографії і на житлових будинках. Тому, для нас зазначений вище факт тісної співпраці архітектора та оздоблювача є одним із ключових, оскільки завдяки ньому стає зрозумілим, що 
зразки музичної іконографії, які ми знаходимо в середмісті Львова, виникли там не випадково і їх дослідження може виявити нові факти локального, чи більш загального значення.

Відомим є факт перебування 3. Курчинського у тісному контакті з «Молодою музою»мистецькою організацією, яка сформувалась на початку XX ст. на Галичині. I, хоча, вона не вела конкретного обліку членів, які до неї входили, проте відомо, що окрім літераторів, молодомузівцями себе вважали українці: композитор С. Людкевич, скульптор М. Паращук, живописець І. Северин, скрипаль і художник І. Косинин, письменник М. Яцків та поляки: письменники В. Оркан і Ю. Єдліч, художники К. Сіхульський, В. Блоцький, Ю. Водинський та скульптор 3. Курчинський (Нісевич, 2012, С. 241).

Така «мозаїчна» компанія вже своїм складом декларувала ідею синтезу мистецтв. Серед членів «Молодої музи» помітним було прагнення до запозичення засобів інших видів мистецтв для збагачення та глибшої реалізації власного художнього задуму. В оповіданні «Сфінкс» М. Яцків писав: «Учений орудує системою, маляр і різьбар площиною, музик сферою, актор рухом, а ми тим всім і ще чимось більше. В мертвім слові маємо воскресити краску, пластику, тон, рух, ідею і ще щось більше, і се наша тайна» ${ }^{1}$ (Нісевич, 2012, С. 243). Цю думку можна сміливо називати маніфестом «Молодої музи», адже синтез мистецтв був ключовою рисою творчих пошуків угрупування. Очевидно, що перебуваючи в тісному контакті 3 письменниками-молодомузівцями 3. Курчинський просто не міг не надихатись їхніми ідеями i не реалізовувати їх потім у своїй творчості.

Члени «Молодої музи» за допомогою інших видів мистецтв намагалися наблизити свої твори до музики. Літературними ставали містерії, симфонії та символічні картини. (Нісевич, 2012, С. 243). Показовою в цьому плані є лірична драма В. Пачовського «Ладі й Марені терновий огонь мій», де автор застосовує прийоми композиційної побудови музичного твору, а саме: присутні інтродукція і фінал по краях і сонати терпіння в середині.

Ще одним цікавим фактом $\epsilon$ те, що представники товариства «Молода муза» використовували живописні ілюстрації для своїх творів не як ілюстративний матеріал, а як частину концепції твору, для ії підсилення (Нісевич, 2012, С. 243). 3 такою ж ціллю підходив до декорування архітектурних будівель 3. Курчинський - 3 прагненням не лише реалізувати власне творче «я», а й довести задум архітектора до довершеного втілення.

Продовжуючи аналіз ідеї синтезу мистецтв, спробуємо детальніше показати ії реалізацію в творчості 3. Курчинського. Як пише Ю. Бірюльов, саме ця ідея спонукала митця займатись декоруванням архітектурних споруд i саме тому в даному аспекті його талант проявився надзвичайно яскраво (Biriulow, 2007). Для будівельної естетики початку століття важливим було повне злиття функціонального, образного та естетичного змісту, що, по суті, i було синтезом тільки на іншому рівні. Саме тому органічність взаємодії монументальної пластики в оздобі самої будівлі ставала мірилом якості і довершеності споруди.

Ще однією персоною, яка мала вплив на 3. Курчинського, зокрема у сфері архітектурного декорування був А. Захаревич - однодумець і колега в сфері взаємодії просторових мистецтв, який був на той час одним із провідних архітекторів міста. Для реалізації ідеї синтезу мистецтв у Львові А. Захаревич звертається до досвіду віденської архітектурної школи (О. Вагнер, Й. Гофман). Результатом стало чітке, «режисерське» (Ю. Бірюльов) планування роботи над об'єктом в цілому і тісна співпраця архітектора і скульптора. Сучасники вважали, що ці два митці досягли абсолютного злиття архітектурного та скульптурного (декоративного) начал, завдяки чому створили таку кількість визначних пам'яток (більше двадцяти): «Скульптури Курчинського характеризуються природним входженням в архітектурний організм i зв'язок 3 ним в гармонійному цілому» (Бірюльов, 2015, С. 326).

Варто зазначити, що така плідна співпраця була в Курчинського не лише із А. Захаревичем. Результативними були також роботи 3 Ю. Авіним, Р. Фелінським, Ф. Касселером, Я. Левинським, Ю. Пйонтковським та іншими яскравими представниками львівської архітектурної школи (Бірюльов, 2005).

Через обмеженість джерел стосовно життєвого та творчого шляху 3. Курчинського було прийнято рішення скористатись можливостями сучасних віртуальних комунікацій і спробувати знайти предків митця, які б могли прояснити причини зацікавлення скульптора музичною

\footnotetext{
${ }^{1}$ У творчому доробку 3. Курчинського є погруддя М. Яцківа.
} 
тематикою. В процесі пошуків вдалось вийти на контакти правнука митця - Г. Курчинського i, навіть, зв'язатись 3 ним. В короткій переписці він повідомив, що йому відомо про любов скульптора до музики і те, що він мав можливість іiі слухати, оскільки часто перебував в колах львівської та вроцлавської богеми. Також, правнук розповів з переказів, що в майстерні у Львові в Курчинського був грамофон. Звісно, дана інформація не може претендувати на повноцінне пояснення наявності музичної іконографії в скульптурній оздобі в творчості Курчинського, однак вносить яскраві штрихи в портрет скульптора в даному руслі.

В 1912 році 3. Курчинський висловив своє творче кредо в одному із періодичних видань, заявивши, що художня форма має відповідати ідейному змісту (Biriulow, 2007). Це може означати лише одне - нічого випадкового, чи не продуманого в творчих вирішення митця бути не могло. Саме тому можна з впевненістю заявляти про особливу роль музичних елементів, які так часто використовував скульптор і продовжувати виясняти причину такого зацікавлення.

Висновки. Творчість талановитого львівського скульптора 3 . Курчинського $\epsilon$ багатогранною 3 точки зору стильового та жанрового різноманіття. Його роботи у галузі скульптурного оздоблення будівель та скульптурна пластика існують паралельно із співпрацею з періодичними виданнями, педагогічною діяльністю та іншими видами суспільної активності. Митець був унікальною особистістю, багато граней якої ще мало досліджені. В статті була здійснена спроба пояснити вибір скульптором музичної символіки, як вагомої теми у його творчості і показати які фактори могли на це вплинути. Також вдалося класифікувати жанри, до яких звертався автор і визначити їх художню цінність в контексті епохи.

Перспективи подальшого дослідження даної теми. Творчість 3. Курчинського загалом, та в контексті музичної іконографії зокрема, має безліч невивчених граней для детального осмислення та аналізу. Також перспективними $є$ роботи, пов'язані із зазначеним періодом, оскільки нами було виявлено велику кількість особистостей, які працювали паралельно із 3. Курчинським. Митці, що творили архітектурне тло міста, яким ми захоплюємось сьогодні, залишаються невідомими для науки та широкого загалу. Тому, для відновлення історичної та наукової справедливості, вважаємо подальше дослідження цього періоду архітектурної історії та ii яскравих персоналій надзвичайно продуктивним і необхідним.

\section{ЛIТЕРАТУРА}

1. Баценкова А. (2006) Стиль Ар деко в искусстве Львова межвоенного периода. Автореф. дисс. М., С. 11

2. Бірюльов Ю. (2010) Курчинський Зитмунт. Енциклопедія Львова, Т. 3, С. 706.

3. Бірюльов Ю. (2015) Львівська скульптура від раннього класицизму до авангардизму (середина XVIII - середина ХХ ст.). Л.: Апріорі, С. 319-333

4. Бірюльов Ю. (2005) Мистецтво Львівської сецесії. Л: Центр Європи, 184 с.

5. Жук И. (1989) Декоративная деталь в архитектуре львовского модерна. Автореф. дисс. М.: Московское высшее художественно-промышленное училище

6. Костко Я. (2014) Типологія скульптурного мотиву атланта в архітектурі Львова другої половини $X I X-$ початку XX cm. Вісник ХДАДМ, № 8, С. 61-65

7. Львів. Туристичний путівник (1999). Л.: Центр Європи, С. 154.

8. Матусяк А. (2008) Сецесійний дискурс письменників «Молодої музи». Слово і час, № 6, С. 35-50.

9. Нісевич С. (2012) «Прерафаелітське братство» $i$ «Молода муза» в типологічному аспекті. Наукові записки. Серія «філологічна», вип. 27. Прикарпатський Національний університет імені Василя Стефаника, С. 240-243. 10. Стара львівська
https://www.facebook.com/OldLvivAdvertising/?ref=page_internal

11. Студницька М. (2014) Синтез мистецтв у громадській $і$ житловій архітектурі Галичини першої третини ХХ cm. Retrieved from http://um.etnolog.org.ua/zmist/2014/158.pdf.

12. Хмарний O. Splendid. URL: http://oseledetsmagazine.com.ua/splendid/

13. Biriulow J. (2007) Rzeźba lwowska od połowy XVIII wieku do 1939 roku: Od zapowiedzi klasycyzmu do awangardy. Warszawa, Neriton. S. 195-208

14. Lwów. Ilustrowany przewodnik (2003). Lwów: Centrum Europy, S. 153 